\title{
KEDUDUKAN PUTUSAN PENGADILAN YANG SUDAH BERKEKUATAN HUKUM TETAP DALAM PEMBATALAN SERTIFIKAT HAK ATAS TANAH
}

\author{
Maya Sartika \\ Program Studi Ilmu Hukum Fakultas Hukum \\ Universitas Jabal Ghafur
}

\begin{abstract}
ABSTRAK
Pengadilan merupakan lembaga kehakiman yang independen dalam menyelesaikan atau memutuskan suatu sengketa. Lembaga kekuasaan kehakiman ini merupakan ciri terpenting setiap Negara hukum yang demokratis. Putusan pengadilan yang dijatuhkan terhadap suatu sengketa mempunyai 3 macam kekuatan yaitu: kekuatan mengikat, kekuatan pembuktian dan kekuatan eksekutorial. Dalam hal pembatalan sertifikat hak atas tanah, pengadilan tidak mempunyai kewenangan untuk membatalkan sertifikat tersebut. Pengajuan gugatan ke pengadilan hanya untuk memperoleh kejelasan siapa pemilik yang sah atas tanah yang disengketakan dan untuk menyatakan sertifikat yang bersangkutan tidak mempunyai kekuatan hukum. Kewenangan penerbitan dan pembatalan sertifikat ada pada BPN sebagaimana yang ditentukan dalam Peraturan Presiden No. 10 Tahun 2006 tentang Badan Pertanahan Nasional. Adapun permasalah yang timbul apakah sertifikat yang dinyatakan tidak mempunyai kekuatan hukum oleh pengadilan tetapi belum dibatalkan oleh BPN masih mempunyai kekuatan sebagai akta otentik? Dan apakah perbuatan-perbuatan hukum masih dapat dilakukan atas dasar sertifikat tersebut?
\end{abstract}

Kunci: Kedudukan Putusan Pengadilan

\section{PENDAHULUAN}

Putusan pengadilan merupakan tahap akhir dalam pemeriksaan perkara dipengadilan. Putusan tersebut diharapkan dapat memberikan kepastian hukum dan keadilan kepada para pihak yang berperkara. Putusan hakim adalah suatu pernyataan yang oleh hakim, sebagai pejabat Negara yang diberi wewenang untuk itu, diucapkan di persidangan dan bertujuan untuk mengakhiri atau menyelesaikan suatu perkara atau sengketa antara para pihak.

Abdul Kadir Muhammad memaknai suatu putusan yang sudah mempunyai kekuatan hukum tetap adalah putusan yang menurut ketentuan undang-undang tidak ada kesempatan lagi untuk menggunakan upaya hukum biasa untuk melawan putusan tersebut.

Putusan pengadilan yang sudah mempunyai kekuatan hukum tetap mempunyai 3 (tiga) kekuatan hukum, yaitu:

1. Kekuatan mengikat

2. Kekuatan pembuktian dan

3. Kekuatan eksekutorial.
Jadi dapat dikatakan, dengan adanya putusan yang sudah mempunyai kekuatan hukum tetap sudah tertutup kemungkinan bagi para pihak untuk menggunakan upaya hukum biasa yaitu banding dan kasasi untuk melawan putusan tersebut. Putusan yang sudah mempunyai kekuatan hukum tetap dengan sendirinya bersifat mengikat. Apa yang diputus oleh hakim dianggap benar dan pihak-pihak wajib mematuhi putusan tersebut.

Pasal 1868 jo Pasal 1870 KUH Perdata menyebutkan bahwa putusan hakim adalah akta autentik sehingga putusan hakim tersebut mempunyai kekuatan pembuktian yang sempuma. Kekuatan pembuktian dari putusan yang telah mempunyai kekuatan hukum tetap adalah kekuatan hukum yang diberikan kepada suatu putusan hakim bahwa dengan putusan tersebut telah diperoleh bukti tentang kepastian sesuatu.

Berdasarkan penjelasan tersebut diatas, perlu ditekankan bahwa putusan pengadilan yang telah mempunyai kekuatan hukum tetap mempunyai kekuatan mengikat 
bagi para pihak yang terkait didalamnya untuk patuh dan taat pada putusan tersebut. Putusan tersebut juga mempunyai kekuatan sebagai pembuktian yang sempuma sehingga diperolehnya suatu kepastian hukum. Bertolak belakang dengan teori, dalam praktek suatu putusan pengadilan seolah menjadi kehilangan kekuatannya baik kekuatan mengikat, kekuatan pembuktian maupun kekuatan eksekutorial apabila dihadapkan dengan kewenangan Badan Pertanahan Nasional (BPN) dalam kaitannya dengan pembatalan sertifikat hak atas tanah.

Ditemukan kasus dalam wilayah hukum Pengadilan Negeri Banda Aceh terhadap suatu sertifikat hak milik atas tanah yang berdasarkan putusan pengadilan pada tingkat pertama, banding dan kasasi dinyatakan tidak mempunyai kekuatan hukum, tetapi Badan Pertanahan Nasional belum membatalkan sertifikat tersebut padahal sudah dimohonkan pembatalan sertifikat atas tanah tersebut dengan melampirkan putusan pengadilan yang telah mempunyai kekutan hukum tetap. Bahkan setelah adanya putusan pengadilan yang berkekuatan hukum tetap, BPN mengeluarkan sertifikat Hak Tanggungan (HT) untuk menjamin perlunasan suatu utang yang pada saat itu terhadap objek sengketa telah diletakkan sitajaminan (conservatoir beslag).

Berdasarkan latar belakang tersebut, maka penulis tertarik untuk ditelaah lebih lanjut mengenai kedudukan putusan pengadilan yang sudah berkekuatan hukum.Telaah ini selanjutnya disusun dalam sebuah penelitian dengan judul" Kedudukan Putusan Pengadilan Yang Sudah Berkekuatan Hukum Tetap Dalam Pembatalan Sertifikat Hak Atas Tanah “.

Sehubungan hal tersebut diatas maka yang menjadi permasalahan yang ingin diteliti yaitu:

1. Bagaimanakah kekutan hukum sertifikat hak atas tanah yang telah dinyatakan tidak mempunyai kekuatan hukum oleh pengadilan dan belum dibatalkan oleh BPN
2. Apakah perbuatan-perbuatan hukum dapat dilakukan atas dasar sertifikat tersebut.

\section{ANALISIS TERHADAP SERTIFIKAT YANG DINYATAKAN TIDAK MEMPUNYAI KEKUATAN HUKUM OLEH PENGADILAN.}

Penyelenggaraan pendaftaran tanah di seluruh wilayah Republik Indonesia bertujuan untuk memberikan kepastian hukum dan perlindungan hukum bagi pemegang hak atas tanah, sehingga sengketa kepemilikan hak atas tanah dapat diminimalisir. Dalam mekanisme pendaftaran tanah, setelah semua tahapan pendaftaran tanah dilakukan, maka BPN mengeluarkan sertifikat sebagai tanda bukti hak atas tanah.

Mengingat sertifikat dibuat dan diterbitkan oleh pejabat tata usaha Negara maka sertifikat digolongkan pada akta otentik. Kekuatan pembuktiannya sama dengan kekuatan pembuktian akta otentik. Pada dasarnya dalam akta otentik dikenal tiga macam kekuatan bukti yaitu:

1. Kekuatan bukti lahir.

Kekuatan bukti lahir berkaitan dengan syarat-syarat formal suatu akta otentik dipenuhi atau tidak. Apabila syarat-syarat formal dipenuhi, maka bentuk yang tampaknya dari luar secara lahiriah sebagai akta otentik dianggap sebagai akta otentik sepanjang tidak dapat dibuktikan sebaliknya.

2. Kekuatan bukti formal;

Kekuatan bukti formal berkaitan dengan soal kebenaran peristiwa yang disebutkan dalam akta otentik. Artinya pejabat dan pihak-pihak yang berkepentingan menerangkan dan melakukan seperti disebutkan dalam akta otentik dan benar demikian adanya. Jadi formalitas yang ditentukan Undang-undang benar-benar dipenuhi.

3. Kekuatan bukti materil.

Kekuatan bukti materiil berkaitan dengan kebenaran isi akta otentik. Artinya bahwa benar yang tercantum dalam akta otentik seperti menurut kenyataannya. Ketiga 
kekuatan bukti tersebut tidaklah mutlak, artinya masih dimungkinkan adanya bukti lawan yang membuktikan sebaliknya. Pihakpihak yang merasa dirugikan dengan dikeluarkannya akta otentik tersebut maka dapat mengajukan gugatan ke pengadilan.

Penyelesaian sengketa hak atas tanah di Pengadilan memberikan kewenangan kepada pengadilan untuk menyelesaikan sengketa tersebut berdasarkan hukum acara yang berlaku. Para pihak yang terlibat harus tunduk dan patuh pada prosedur dan ketentuan hukum acara yang berlaku. Jimmly Asshiddiqie mengutip pendapat sjachran Basah tentang definisi peradilan yang merupakan proses untuk rnemberikan keadilan dalarn rangka menegakkan hukum. Peradilan adalah segala sesuatu yang bertalian dengan tugas memutus perkara dengan menerapkan hukum, menemukan hukum in concreto dalam mempertahankan dan menjamin ditaatinya hukum materiil dengan menggunakan cara procedural yang diterapkan oleh hukum formal, sedangkan pengadilan adalah badan atau wadah yang memberikan peradilan.

Berdasarkan apa yang dikemukakan oleh Sjachran Basah tersebut pengadilan yang diberikan kewenangan untuk memutuskan sengketa-sengketa hukum dengan menerapkan aturan hukum yang berlaku dan menjamin ditaatinya hukum materiil, maka suatu putusan yang dikeluarkan oleh pengadilan tentu mempunyai kekuatan hukum baik kekuatan mengikat, kekuatan pembuktian maupun kekuatan eksekutorial.

Dalarn hal sengketa hak atas tanah putusan pengadilan diperlukan untuk menentukan siapa pemilik yang sah atas suatu bidang tanah yang disengketakan, sehingga diperolehnya suatu kepastian hukum. Mengingat system pendaftaran tanah di Indonesia adalah bersifat publikasi negative, maka sangat dimungkinkan bagi siapa saja untuk membuktikan bahwa dirinya adalah pemilik yang sah atas suatu bidang tanah meskipun sudah ada sertiftkat hak atas tanah yang diterbitkan oleh BPN.
Dalam hal inilah suatu putusan pengadilan sangat diperlukan untuk menyelesaikan sengketa yang bersangkutan.

Putusan situangkan dalam bentuk tertulis yang bertujuan untuk dapat digunakan sebagai alat bukti bagi para pihak yang mungkin diperlukannya untuk mengajukan banding, kasasi atau pelaksanaannya. Arti putusan itu sendiri dalam pembuktian ialah bahwa dengan putusan tersebut telah diperoleh suatu kepastian tentang sesuatu. Putusan akhir dalam hukum acara perdata diklasifikasikan menjadi 3 jenis, yaitu :

1. Putusan kondemnator,

2. Putusan declaratory,

3. Putusan konstitutif.

Putusan kondemnator adalah putusan yang bersifat menghukum. Dalam perkara perdata, hukuman diartikan sebagai kewajiban untuk memenuhi prestasi yang dibebankan oleh Hakim. Hak: atas suatu prestasi yang telah ditetapkan oleh Hakim dalam putusan kondemnator dapat dilaksanakan dengan pak:saan.

Putusan deklarator adalah putusan yang bersifat menyatakan hukum atau menegaskan suatu keadaan hukum sematamata. Dengan kata lain, putusan deklarator bersifat penetapan saja tentang keadaan hukum, tidak bersifat mengadili karena tidak: ada sengketa.

Putusan konstitutif adalah putusan yang bersifat menghentikan keadaan hukum lama atau menimbulkan keadaan hukum baru. Dalam putusan konstitutif tidak diperlukan pelaksanaan dengan paksaan karena dengan diucapkannya putusan itu sekaligus keadaan hukum lama berhenti dan timbul keadaan hukum baru.

Adanya putusan pengadilan yang berkekuatan hukum tetap terhadap suatu sertifikat hak: atas tanah yang menyatak:an bahwa sertifikat tersebut tidak: mempunyai kekuatan hukum menyebabkan sertifikat yang bersangkutan tidak: berlaku lagi meskipun belum dibatalkan oleh BPN. Putusan dalam sengketa ini diklasifikasikan pada putusan konstitutif. Putusan yang 
mana tidak: memerlukan adanya pelak:sanaan dengan pak:saan karena dengan diucapkannya putusan tersebut keadaan hukum lama berhenti (sertifikat yang sudah diterbitkan menjadi tidak mempunyai kekuatan hukum) dan timbul keadaan hukum baru (pihak: yang menang sebagai pihak: yang sah atas bidang tanah yang di sengketak:an).

Bertolak belakang dengan teori, dalam praktek suatu sertifikat hak atas tanah yang sudah dinyatakan tidak mempunyai kekuatan hukum oleh pengadilan tingkat pertama, kedua dan kasasi tetapi sertifikat tersebut belum dibatalkan oleh BPN dan bahkan masih dilakukan perbuatanperbuatan hukum yang didasarkan atas sertifikat tersebut. Fakta ini menimbulkan pertanyaan apakah pernyataan yang menyebutkan bahwa suatu putusan pengadilan yang berkekuatan hukum tetap mengikat para pihak untuk tunduk dan patuh pada putusan tersebut tidak berlaku terhadap BPN selaku salah satu pihak dalam perkara?

Dan apakah selama BPN belum membatalkan sertifikat tersebut maka masih ada kemungkinan untuk dilakukan perbuatan-perbuatan hukum yang didasarkan pada sertifikat tersebut?

Jika ditinjau dari proses pendaftaran tanah untuk pertama kali sebelum sampai pada penerbitan sertifikat hams melalui beberapa tahapan, yaitu pengumpulan dan pengolahan data fisik yang pertama dilakukan adalah dan pemetaan yang meliputi :

a. Pembuatan peta dasar pendaftaran,

b. Penepatan batas bidang-bidang tanah,

c. Pengukuran dan pemetaan bidang-bidang tanah dan pembuatan peta pendaftaran,

d. Pembuatan daftar tanah,

e. Pembuatan surat ukur.

Semua tahapan tersebut harus dilakukan dengan teliti terutama pada tahap penetapan batas-batas bidang tanah yang harus dihadiri oleh pihak-pihak yang berkepentingan, sehingga diperoleh kebenaran dan kepastian tentang bidang tanah yang bersangkutan. setelah semua tahapan pengumpulan dan pengolahan data fisik dilakukan kemudian dilanjutkan dengan pembuktian dan pembukuannya. Meskipun prosedur yang ditentukan oleh Undangundang telah dijalankan sebagaimana mestinya, tidaklah menutup kemungkinan untuk terjadinya sengketa. Oleh karena itu sertifikat yang diterbitkan oleh BPN tidaklah bersifat mutlak artinya masih dimungkinkan adanya bukti lawan.

Menurut Pasal 32 ayat (2) PP No. 24 Tahtm 1997 tentang Penda:ftaran Tanah disebutkan:

"Dalam hal atas suatu bidang tanah sudah diterbitkan sertifikat secara sah atas nama orang atau badan hukum yang memperoleh tanah tersebut dengan itikad baik dan secara nyata menguasainya, maka pihak lain yang merasa mempunyai hak atas tanah itu tidak dapat lagi menuntut pelaksanaan hak tersebut apabila dalam jangka waktu 5 (lima) tahun sejak diterbitkannya sertifikat itu tidak mengajukan keberatan secara tertulis kepada pemegang sertifikat dan Kepala Kantor Pertanahan yang bersangkutan ataupun tidak mengajukan gugatan ke Pengadilan mengenai penguasaan tanah atau penerbitan sertifikat tersebut."

Ketentuan Pasal 32 ayat (2) PP No. 24 Tahun 1997 menunjukkan bahwa setelah sertifikat diterbitkan oleh BPN, Undangundang masih memberikan kesempatan bagi pihak-pihak lain yang merasa dirugikan dengan dikeluarkannya sertifikat tersebut untuk melakukan upaya hukum. Jangka waktu yang ditetapkan oleh Undang-undang adalah 5 tahun baik pengajuan keberatan secara tertulis ke BPN atau pengajuan gugatan ke Pengadilan.

Apabila sebelum diterbitkannya sertifikat hak atas tanah, terhadap tanah yang bersangkutan sudah dalam sengketa maka berdasarkan ketentuan PP No. 24 Tahun 1997 tanah tersebut belum dapat diterbitkan sertifikat sampai ada putusan pengadilan yang menyatakan siapa pemilik yang sah atas tanah yang disengketakan. Hal ini sebagaimana yang disebutkan dalam Pasal 30 dan pasal 31 PP No. 24 Tahun 
1997 menyebutkan bahwa apabila tanah dalam sengketa baik yang diajukan ke pengadilan ataupun tidak, harus dibuat catatan dalam buku tanah bahwa tanah tersebut dalam sengketa dan penerbitan sertifikatnya ditangguhkan sampai catatan tersebut dihapus.

Didalam peraturan perundangundangan yang mengatur tentang hak atas tanah, salah satu factor yang menyebabkan hak atas tanah hapus adalah karena adanya putusan pengadilan yang telah mempunyai kekuatan hukum tetap. Badan Pertanahan nasional (BPN) sebagai lembaga yang diberikan kewenangan untuk menerbitkan dan membatalkan sertifikat hak atas tanah sebagaimana disebutkan dalam Pasal 3 huruf t Peraturan Presiden No. 10 Tahun 2006 Tentang Badan Pertanahan Nasional yang menyebutkan BPN menyelenggarakan fungsi pembatalan dan penghentian hubungan hukum antara orang, dan/ atau badan hukum dengan tanah sesuai dengan ketentuan peraturan perundang-undangan yang berlaku, maka pengadilan tidak mempunyai kewenangan untuk membatalkan sertifikat tersebut.

Pembatalan pada dasarnya adalah suatu perbuatan yang bermaksud memutuskan, menghentikan atau menghapuskan sesuatu hubungan hukum. Didalam Pasal 1 angka 14 Peraturan Menteri Agraria/ Kepala Badan Pertanahan Nasional No. 9 Tahun 1999 tentang Tata Cara Pemberian dan Pernbatalan Rak atas Tanah Negara dan Hak Pengelolaan yang selanjutnya disebut PMA No. 9 Tahun 1999 menyebutkan bahwa pembatalan hak atas tanah adalah pembatalan keputusan pemberian hak atas tanah atau sertifikat hak atas tanah karena keputusan tersebut mengandung cacat hukum administrasi dalam penerbitannya atau untuk melaksanakan putusan pengadilan yang telah memperoleh kekuatan hukurn tetap.

Keputusan pembatalan hak atas tanah karena melaksanakan putusan pengadilan yang telah memperoleh kekuatan hukum tetap diterbitkan atas permohonan pihak yang berkepentingan. Jadi dalam hal ini, para pihak sendiri yang harus mengajukan permohonan pembatalan. Amar putusan pengadilan yang telah mernperoleh kekuatan hukurn tetap meliputi dinyatakan batal atau tidak mempunyai kekuatan hukurn atau yang pada intinya sama dengan itu.

Permohonan pembatalan hak atas tanah karena melaksanakan putusan pengadilan dapat diajukan langsung kepada Menteri atau Kepala Kantor Wilayah atau melalui Kepala Kantor Pertanahan. Dalam permohonan pernbatalan hak atas tanah tersebut mernuat:

1. Keterangan rnengenai pemohon,

2. Keterangan mengenai tanahnya,

3. Alasan permohonan pembatalan dan bukti-bukti lain yang mendukung.

Didalam Pasal 126 ayat (2) PMA No. 9 Tahun 1999 juga disebutkan bahwa dalam permohonan pembatalan harus melampirkan: foto kopi identitas, foto kopi surat keputusan/ sertifikat, foto kopi akta pendirian badan hukum, foto kopi putusan pengadilan dan tingkat pertama sampai dengan putusan terakhir, berita acara eksekusi atau surat-surat lainnya yang berkaitan dengan permohonan pembatalan, Selanjutnya permohonan tersebut diajukan melalui Kepala Kantor Pertanahan yang akan memeriksa dan meneliti kelengkapan data yuridis dan data fisik, mencatat dalam formulir isian, memberikan tanda terima berkas permohonan pembatalan dan memberitahukan kepada pemohon untuk melengkapi data yuridis dan data fisik jika masih diperlukan. Selanjutnya Kepala Kantor Pertanahan akan menyampaikan berkas permohonan tersebut kepada Menteri.

Menteri akan meneliti kelengkapan dan kebenaran data yuridis dan data fisik permohonan serta memeriksa kelayakan permohonan tersebut dapat atau tidaknya amar putusan pengadilan dilaksanakan. Selanjutnya menteri akan memutuskan permohonan tersebut dengan menerbitkan keputusan pembatalan hak atas tanah yang dimohon atau memberitahukan bahwa amar 
putusan pengadilan tidak dapat dilaksanakan disertai dengan alasan dan pertimbangannya. Dalam hal Menteri tidak dapat melaksanakan amar putusan pengdilan. Menteri dapat memohon fatwa kepada Mahkamah Agung dalam pelaksanaan amar putusan pengadilan tersebut.

Wewenang Menteri Dalam Negeri untuk membatalkan sertifikat tanah tersebut adalah sesuai dengan Putusan Mahkamah Agung Republik Indonesia tertanggal $3 \mathrm{Mei}$ 1969 No. Reg 350/K/Sip/_1968 dan putusan tertanggal 5 September 1973 No. Reg 716/K/Sip/1973 yang dalam kaedah hukumnya disebutkan bahwa: " pengeluaran/ pencabutan dan pembatalan surat sertifikat adalah semata-mata wewenang dari Kantor Pendaftaran Tanah dan Pengawasan Pendaftaran Tanah, bukan termasuk wewenang pengadilan Negeri, maka gugatan penggugat mengenai pencabutan/pembtalan sertifikat No.171 tidak dapat diterima"

Sudikno Mertokusumo dalam bukunya Hukum Acara Perdata Indonesia menyebutkan bahwa pembatalan sertifikat hak milik yang dikeluarkan oleh instansi Agraria (BPN) secara sah tidak termasuk wewenang pengadilan, melainkan sematamata termasuk wewenang administrasi. Pembatalan surat bukti tersebut harus dimintakan oleh pihak yang dimenangkan pengadilan kepada BPN berdasarkan putusan pengadilan yang diperolehnya.

Berdasarkan pendapat Sudikno tersebut menunjukkan bahwa putusan pengadilan disini tidak bersifat eksekutorial. Kewenangan pengadilan hanya sampai pada pemyataan suatu sertifikat batal atau tidak mempunyai kekuatan hukum dan menunjuk pihak yang dimenangkan sebagai pihak yang sah atas bidang tanah yang disengketakan. Ketentuan yang menunjukkan kewenangan pembatalan sertifikat hak atas tanah ada pada BPN tidaklah menunjukkan bahwa BPN dapat secara sewenang-wenang mengacuhkan putusan Pengadilan. Putusan pengadilan tetap mempunyai kekuatan mengikat bagi para pihak untuk tunduk dan patuh pada putusan tersebut.

Ketentuan Undang - undang menentukan bahwa setelah adanya putusan pengadilan yang berkekuatan hukum tetap, BPN harus menindaklanjuti putusan pengadilan tersebut. Sebagaimana yang disebutkan dalam PMA No. 9 Tahun 1999 bahwa pembatalan hak atas tanah yang didalarnnya termasuk juga pembatalan sertifikat hak atas tanah disebabkan oleh adanya dua factor yaitu:

1. Karena adanya cacat hukum administrative

2. Karena adanya putusan pengadilan yang telah memperoleh kekuatan hukum tetap.

Ditinjau dari kekuatan sertifikat hak atas tanah, suatu sertifikat yang diterbitkan oleh BPN setelah memenuhi semua prosedur yang ditentukan dalam PP No. 24 Tahun 1997 mempunyai kekuatan hukum sebagai akta otentik sejauh tidak dibuktikan sebaliknya. Apabila sertifikat tersebut telah dapat dibuktikan sebaliknya di muka sidang pengadilan dan dinyatakan tidak mempunyai kekuatan hukum berdasarkan putusan pengadilan yang berkekuatan hukum tetap, maka sertifikat tersebut menjadi tidak mempunyai kekuatan lagi sebagai akta otentik meskipun belum dilakukan pembatalan oleh BPN. Konsekuensi lain dari adanya putusan ini adalah tidak dapat lagi dilakukan perbuatan-perbuatan hukum yang didasarkan pada sertifikat tersebut. Adapun perbuatan- perbuatan hukum yang tetap dilakukan baik ketika tanah dalam sengketa ataupun setelah adanya putusan pengadilan menyebabkan perbuatanperbuatan hukum tersebut batal demi hukum.

Timbulnya permasalahan dalam pembatalan sertifikat hak atas tanah adalah terletak pada putusan pengadilan yang ternyata tidak secara serta merta setelah dibacakan putusan dapat membatalkan sertifikat tersebut. Para pihak harus mengajukan lagi permohonan pembatalan kepada BPN dengan melampirkan putusan pengadilan yang nantinya BPN akan menindaklanjuti putusan tersebut. Bahkan 
apabila BPN tidak menindaklanjuti putusan pengadilan untuk membatalkan sertifikat tersebut, BPN tidak terikat dengan sanksi hukum apapun. Hal inilahyang menyebabkan putusan pengadilan dapat diabaikan oleh BPN.

Selanjutnya dikemukakan juga dalam PMA No. 9 Tahun 1999 bahwa permohonan pembatalan yang diajukan oleh para pihak dengan melampirkan putusan pengadilan akan terlebih dahulu dipertimbangkan oleh menteri untuk dibatalkan atau tidak. Adanya persetujuan menteri untuk mempertimbangkan suatu putusan pengadilan yang berkekuatan hukum tetap boleh ditindak lanjuti atau tidak menunjukan Pengadilan sebagai lembaga yudikatif yang dalam menjalankan tugasnya menyelesaikan berbagai permasalahan sehingga memberikan kepastian hukum bagi masyarakat tidak terwujud.

\section{PENUTUP}

Berdasarkan uraian yang telah dikemukakan diatas, maka pada bagian penutup ini dkemukakan beberapa kesimpulan dan disertai dengan saran.

\section{A. Kesimpulan}

1. Kedudukan sertifikat hak atas tanah yang dinyatakan tidak mempunyai kekuatan hukum oleh pengadilan walaupun belum dibatalkan oleh BPN secara teoritis sertifikat tersebut sudah tidak mempunyai kekuatan sebagai akta otentik. Oleh karena itu segala perbuatan yang didasarkan pada sertifikat tersebut batal demi hukum.

2. Dalam pembatalan sertifikat hak atas tanah disebabkan Ketidakjelasan aturan tentang kedudukan putusan Mahkamah Agung dan Peraturan Menteri. Ketidakjelasan ini menyebabkan adanya ketidak pastian dalam pelaksanaanya. Putusan pengadilan menjadi tidak mempunyai kekuatan apapun apabila dihadapkan dengan kewenangan BPN dalam pembatalan sertifikat hak atas tanah. pengajuan gugatan ke pengadilan tidak menyelesaikan permasalahan melainkan masyarakat malah dirugikan mengingat berperkara di pengadilan tidaklah mudah, membutuhkan waktu dan biaya yang tidak sedikit tetapi hasil yang diharapkan tidak ada.

\section{B. Saran}

1. Disaran kepada Badan Pertanahan Nasional dalam pembatalan sertifikat hak atas tanah, seharusnya jangan merugikan masyarakat, menginagat perkara di pengadilan tidaklah mudah dan membutuhkan waktu serta biaya.

\section{DAFTAR PUSTAKA}

\section{A. Buku-buku}

Abdulkadir Muhammad, Hukum Acara perdata Indonesia, Citra Aditya Bhakti, Bandung, 2000.

Bachtiar Effendi, Kumpulan Tulisan Tentang Hukum Tanah, Alumni, Bandung, 1993.

Jimmly Asshiddiqie, Pokok-Pokok Hukum Tata Negara Indonesia Pasca Reformasi, Bhuana Ilmu Populer Kelompok Gramedia, Jakarta, 2007.

Rusmadi Murad, Penyelesaian Sengketa Hukum atas Tanah, Alumni, Bandung, 1991.

Sudikno Mertokusumo, HukumAcara Perdata Indonesia, Liberty, Yogyakarta, 2006.

\section{B. Peraturan Perundang-undangan}

Undang-Undang No. 5 Tahun I 960 tentang Peraturan Dasar Pokok-Pokok Agraria.

Undang-Undang No. 48 Tahun 2009 tentang Kekuasaan Kehakiman. 
Peraturan Presiden Republik Indonesia No. 10 Tahun 2006 tentang Badan Pertanahan Nasional.

Peraturan Presiden Republik Indonesia No. 24 Tahun 1997 tentang Pendaftaran Tanah.

Peraturan Menteri Agraria/ Kepala Badan Pertanahan nasional No. 31997 tentang Ketentuan Pelaksanaan
Peraturan Pemerintah No. 24

Tahun 1997

Pendaftaran Tanah

Peraturan Menteri Agraria/ Kepala Badan Pertanahan Nasional No. 9 Tahun 1999 tentang Tata Cara Pemberian dan Pembatalan Hak Atas Tanah Negara dan Hak: Pengelolaan. 